Journal of History Culture and Art Research (ISSN: 2147-0626)

Tarih Kültür ve Sanat Araştırmaları Dergisi

Revue des Recherches en Histoire Culture et Art

مجلة البحوث التاريخية و الثقافية والفنية
Vol. 7, No. 2, June 2018

Copyright (C) Karabuk University

http://kutaksam.karabuk.edu.tr

\title{
DOI: 10.7596/taksad.v7i2.1583
}

Citation: Lazareva, G. I., Efremova, L. A., Rusetskaya, E. A., Ulibina, L. K., \& Okorokova, O. A. (2018). The Role of Culture in the Development of Society and the Opportunities to Finance It in Russia. Journal of History Culture and Art Research, 7(2), 72-86. doi:http://dx.doi.org/10.7596/taksad.v7i2.1583

\section{The Role of Culture in the Development of Society and the Opportunities to Finance It in Russia}

\author{
Galina Ivanovna Lazareva ${ }^{1}$, Lyudmila Anatolyevna Efremova², \\ Elvira Antsasovna Rusetskaya ${ }^{3}$, Lubov Konstantinovna Ulibina ${ }^{4}$, \\ Olga Alekseevna Okorokova 5
}

\begin{abstract}
In a civilised society a point of view on acknowledging culture as one of the most significant resources of socio-economic development was formed. The development of culture in Russian society faces multiple problems. In "The Fundamentals of the Legislation of the Russian Federation on Culture" the duties and responsibilities of state administration bodies for the effective development of this sphere and financial support of cultural activity are proclaimed. Defining the boundaries of state regulation of financial relations in culture and leisure sphere is mainly dependant on the type of social and budgetary policy of the state that influence directly the degree of implementing the declared priorities and on the guarantees to the population of a country in the field of culture. These problems constitute the subject matter of the given research. The condition of the objects of culture and the list of tasks that are solved with its assistance prove the necessity to specify the methodological principles of implementing the state policy in the sphere of culture. The elements of scientific novelty consist in justifying the necessity to develop a complex of measures of improving forms and methods of financial support of culture with the use of the elements of functionally oriented financing of industry expenses.
\end{abstract}

Keywords: Functions of culture, Financial support of industry.

\footnotetext{
${ }^{1}$ Stavropol Institute of Cooperation (Branch) Belgorod University of Cooperation, Economics and Law (BUKEP) 36, Goleneva Street, Stavropol, Russia, 355000. E-mail: galina.lazareva@mq.edu.au

${ }^{2}$ Kuban State Technological University (KubSTU) 2, Moskovskaya st., Krasnodar, Russia, 350072.

${ }^{3}$ North Caucasus Federal University (NCFU) 1, Pushkina Streel, Stavropol, Russia, 355009.

${ }^{4}$ Kuban State Agrarian University (Kuban SAU) 13, Kalinina Street, Krasnodar, Russia, 350044.

${ }^{5}$ Kuban State Agrarian University (Kuban SAU) 13, Kalinina street, Krasnodar, Russia, 350044.
} 


\section{Introduction}

At the turn of the century in a civilised society the attitude to culture changed dramatically, a point of view on acknowledging culture as one of the most significant resources of socio-economic development was formed. In October 1999 the World Bank organised a conference named "Culture counts" in Florence. Assessing the importance of the given event we can note the following tendencies. First of all, acknowledging the increasing significance of culture for socio-economic development of modern society by international organisations. Secondly, the inclusion of culture into the priority orientations of government policy of particular states; it indicates the necessity to expand the range of scientific research in order to "adequately assess the role of culture in social life of a person" [17] and society.

"Culture should be considered as a set of distinctive features inherent to society or to a social group: spiritual and material, intellectual and emotional ones. Apart from art and literature it comprises the way of life, the ability to coexist, systems of values, traditions and beliefs" [4].

The role of culture in Russian society and its development face multiple problems starting from the terminology implemented in this sphere and ending with the impact of "the modern tendencies in the development of a new society that is being formed in the conditions of rising democracy, market economy and freedom" [18]. At the same time we should take into account the number of critical situations in the Russian economy and finances during 2008-2014 as well as the imposing international economic sanctions; this fact could not but affect the content and opportunities of financing the Russian state cultural policy. The intensification of the processes of the formation of new types of establishments and organisations, the development of new technologies of financial management in the non-profit sector of economy necessitate the further development of legal norms that establish an order of financial support to services in the sphere of culture at all the levels of budgetary system. These positions determine the relevance of the given research.

\section{Methodology}

The subject matter of the research is a complex of financial-economic and organisational-legal relations that are connected with the implementation of main orientations of the state policy in the sphere of culture. The methodological and informational basis of the article was made up of the provisions of the economic theory that studies the functioning of public sector and the nature of public good; the works of leading scientists on the theory of state and municipal finances; normative legal acts that regulate the process of financial support of state services in the sphere of culture; publications in periodical relevant journals; statistical data; Internet sources; the materials of the Ministry of Finance of the Russian Federation, the Ministry of Culture of the Russian Federation; other official sources of information.

The validity of the results and recommendations is provided with the complex application of general scientific methods such as the dialectical means of cognitions, the system approach, the methods of 
structural and functional analysis, the principles of formal logic, the presentation of table material and others.

\section{Results}

\subsection{Assessing the role of culture in the development of society}

The development of modern culture in Russian is rather controversial. The system of management activity ensuring "the successful functioning and development of the national culture in its sectoral sense is based on a whole series of normative legal acts. The main list of such functions and kinds of activities is formulated in "The Fundamentals of the Legislation of the Russian Federation on Culture" [7]. The tasks of the legislation of the Russian Federation on culture are as follows:

- Providing and protecting the rights of the citizens of the Russian Federation for cultural activity;

- Creating legal guarantees of free cultural activity of citizens' unions, peoples and other ethnic groups in the Russian Federation;

- Defining the principles and legal norms of relations between the subjects of cultural activity;

- Defining the principles of state culture policy, legal norms of state support of culture and guarantees of laissez-faire attitude to creative processes [15].

The state finances and budget as a centralised monetary fund are considered as a most important instrument of state economic regulation and culture regulation in particular. The modern researches connected with studying the economic mechanism of the cultural sphere demonstrate that the type of social and budgetary policy of the state influences greatly the process of state regulation of financial relations in culture and leisure sphere. At the same time it is indicated that the main problems include economic and organisational-legal issues that "directly affect the level of realisation of the proclaimed priorities and social guarantees for the population of the country in the sphere of culture" $[19,13,20]$.

Cultural industry performing the intended socio-economic functions influence directly and indirectly the final economic outcomes of a country by means of spiritual enrichment of people who make an important condition for increasing quality of "human capital". The economy culture industry as a set of enterprises, establishments and organisations and as a subject of economy arranges the content cultural life and affects significantly the investment and tourism attractiveness of a country and its regions. Providing population's employment on the relevant market of services the establishments of culture participate in solving problems of social policy of the state.

In modern conditions there are no doubts about the fact that "culture is a system-forming factor of consolidating and developing society at the national and regional scale" [20].

"Culture" industry is represented by a large number of organisations and establishments that carry out various activities and follow diverse courses of action each of which requires taking into account their 
specifics in the process of budgetary financing. The instruments of state regulation, the methods of expenses planning and their financial support must provide "the realisation of conceptual principles of the functioning of cultural sphere from the standpoint of effectiveness and efficiency of the use of financial resources, budgetary or extra-budgetary" [7].

Studying the issues of using the instruments of budgetary policy of a country in financing culture requires consideration of the notion of state policy in the sphere of culture. A number of well-known cultural scientists support the following points of views on the definition of cultural policy. A.Ya. Flier defines cultural policy as "a set of scientifically justified views and undertakings on comprehensive socio-cultural modernisation of society and structural reforms of all the system of institutions; the system of new principles of balancing state and social constituents of public and cultural life" [22]. Cultural management is carried out on the basis of a complex of operational and perspective actions on solving the issues of current institutions "aimed at providing expanded reproduction of relevant cultural forms within the limits of financial funds, personnel, instruments and technologies that people possess presently" [22]. Other authors claim that "cultural policy is the formation of priority directions of the development of cultural sphere at federal, regional and local levels" [20].

The authors of the given research consider state policy as an important constituent of social policy and as one of conditions of solving the problem of improving "human capital" and, thus, highlight its complex social, cultural and educational character. The policy in cultural sphere must be positioned as a direction of state and public activity that requires regulating form the part of the state taking into account the peculiarities of the combination of goals, tasks and undertakings in the use of cultural heritage to develop the nation that solves them in accordance with social preferences. In this regard a wide range of its goals and tasks can be grouped in the following way. First, cultural policy must be considered from the standpoint of opportunity of providing the citizen of a country with freedom of social, creative and political activity in encouraging creativity in the sphere culture and art. Second, it is necessary to guarantee certain cultural creative services and kinds of activity financed by budgetary funds for the citizens. Third, to develop and improve the cultural policy of the Russian Federation it is necessary to solve issues of country's integrating into the world cultural space and to form cultural programmes aimed at popularising Russian culture abroad.

\subsection{Characteristics of main problems in realising state policy in the sphere of culture}

For quite a long period of time (approximately ten-fifteen recent years) there have been a number of issues reflecting the essential gap between theory and practice in fulfilling tasks of state policy in the sphere of culture. The authors of theoretical scientific researches acknowledge and prove the significance of social good and the necessity to take into account "the character of expenses and the result achieved; the forms of state participation in providing social good, etc." [5]. In case of an attempt to generalise the experience of the existing, legally provided financial mechanism for the functioning of "culture" industry, we come to 
the conclusion that there are insufficiently developed and used methods and instruments that could contribute to solving the issues of expanding the economic and financial autonomy of cultural institutions.

Due to the fact that the market mechanism is not in a position to take responsibility for the solution of all social and economic problems of society taking into account the specifics of its principles, it becomes necessary to create appropriate state institutions for performing the functions of the sectoral economic mechanism that have certain resources to fulfill the functions assigned to the authorities. These resources include the state ownership and centralised monetary funds, the effectiveness of the practical use of which is to a large extent determined by the availability of a corresponding financial theory. "Financial theories do not exist in themselves; they always serve as the basis, the ground for choosing a particular direction of financial policy that corresponds to the specific goals and tasks that the state faces" [21].

Long-term experience of conducting research by the authors of this article makes it possible to pay attention to the manifestation of a significant contradiction. On the one hand, the methodology for the development of socio-cultural sectors, the main principles of the policy in the field of budgetary financing of culture are formulated and justified. On the one hand, the main undertakings of the budgetary policy are declarative in nature; they do not have a corresponding financial and organisational-legal mechanism for their implementation.

The idea expressed by N.A. Vaganova more than a decade ago is still rather relevant. She wrote, "When proving the effectiveness of investments into culture and the exact benefit that a country obtains from them we should explain to the legislative and executive authorities of all levels that to support culture it is possible to use different sources of financing" [12]. The dynamics of the state of affairs in the field of financing the cultural industry in the Russian Federation during 2007-2020 will be described below. "But when the state is not capable of providing culture with what is necessary, it must at least create the required conditions in which extra-budgetary funds could be involved into financing culture" [12].

Federal expenditures on culture during 2008-2010 changed from 83 to 68 billion of Russian roubles per year that makes $0.8-1.3 \%$ of the total amount of budgetary allocation from the federal budget [23]. Naturally, such poor funding does not correlate at all with the role that culture must perform in forming the personality of a citizen of a developed country. The indicated financial funds cannot correspond to realisation of those ambitious goals that are proclaimed annually in the legislation on culture.

There is a justified opinion that "culture" industry provided an example of a new approach to financing the socio-cultural sphere, the essence of which was the transition to financing functions performed by cultural institutions instead of allocating budget funds to finance their network. Already in 2008 one of the authors of this research called this approach "a functionally oriented financing of culture". This conclusion was to a large extent justified by a positive example of the Fund for the Development of Culture created in the sector at the expense of the budget funds of the chief administrator of budgetary funds, as well as by the development of the Federal Target Programme (FTP) "Culture of Russia (2006-2010)". The Federal Target 
Programme "Culture of Russia (2006-2010) approved by the decree of the Government of the Russian Federation from 08.12.2005, No. 740 included the following main objectives:

Preserving cultural heritage of the Russian Federation;

Forming united cultural space;

Creating conditions for preserving and developing cultural potential of the nation;

Proving adaptation of cultural sphere to market conditions, etc. [23].

The passport of the Federal Target Programme "Culture of Russia (2006-2010) envisaged an increase in the amount of financing of programme events at the expense of the budget funds of the federal budget for every year of its realisation from 11.922 billion of Russian roubles in 2006 to 24.473 billion of Russian roubles in 2010. Cash execution of the assignations of the given target programme according to the data of the Federal Treasury made $99.0 \%$ in 2006 and $96.1 \%$ in 2010 respectively.

\subsection{Studying the aspects of interconnection of the policy in the sphere of culture and budgetary policy}

Investigating the main stages in forming and developing the conception of the state cultural policy in Russia clearly demonstrates its interconnection with the main directions of budgetary policy. During the period of the country's economic recovery the Conception of Long-Term Social and Economic Development of the Russian Federation for the period until 2020 was developed and in June 2006 it was approved. The purpose of its development was to define ways and means to ensure in the long run a sustainable improvement in the well-being of Russian citizens in the conditions of a steady growth of the Russian economy [10]. Within its framework the Federal Target Programme (FTP) "Culture of Russia (2012-2018)" was approved to substantiate and finance the state cultural policy. It stated that the development of the Russian Federation at the present stage "is characterized by an increased public attention to culture which has a leading role in the formation of human capital". The programme also recognised the fact that "the implemented set of government measures with the positive dynamics of particular indicators, that could be noticed in the last ten years, has not yet influenced decisively and positively the situation in culture" [24, 25].

When starting to consider the results and tasks of budget funding at the modern stage it should be primarily noted that the Federal Target Programme (FTP) "Culture of Russia (2012-2018)" is realised as one of subprogrammes of the state programme "The Development of Culture and Tourism in 2013-2020". Among the main goals of the state programme "The Development of Culture and Tourism" we can single out the realisation of "the strategic role of culture as a spiritual-moral basis for forming a balanced personality". In the process of the implementation of activities of the programme the financial resources were allocated and disbursed which is shown in table $1[1,2,16]$. 
Table 1. Federal budget expenditure on social sphere, science and culture in 2015-2020

Billions of Russian roubles

\begin{tabular}{|c|c|c|c|c|c|c|}
\hline \multirow[t]{2}{*}{ Indicator } & \multicolumn{2}{|c|}{ Report } & \multirow{2}{*}{$\begin{array}{l}\text { Law } \\
2017\end{array}$} & \multicolumn{3}{|c|}{ Project } \\
\hline & 2015 & 2016 & & 2018 & 2019 & 2020 \\
\hline Federal budget expenditure & 15620.3 & 16403.0 & 16420.3 & 16529.2 & 16373.7 & 17155.3 \\
\hline $\begin{array}{l}\text { State programmes of social sphere } \\
\text { and science, total amount }\end{array}$ & 2412.1 & 2422.2 & 2486.3 & 2501.7 & 2423.9 & 2494.0 \\
\hline $\begin{array}{l}\text { percentage of the total amount of the } \\
\text { federal budget expenditure }\end{array}$ & 15.4 & 14.8 & 15.1 & 15.1 & 14.8 & 14.5 \\
\hline $\begin{array}{l}\text { percentage of the gross domestic } \\
\text { product (GDP) }\end{array}$ & 2.9 & 2.8 & 2.7 & 2.6 & 2.4 & 2.3 \\
\hline including: & & & & & & \\
\hline $\begin{array}{l}\text { "The Development of Culture and } \\
\text { Tourism in 2013-2020" }\end{array}$ & 94.3 & 90.6 & 98.8 & 92.5 & 78.2 & 77.5 \\
\hline $\begin{array}{l}\text { percentage of the total amount of the } \\
\text { federal budget expenditure }\end{array}$ & 0.6 & 0.6 & 0.6 & 0.6 & 0.5 & 0.5 \\
\hline
\end{tabular}

After the analysis of the data presented in table 1 from the standpoint of the amount of budget funding of culture and their share in the total amount of federal budget expenditure no positive tendencies were found. In 2008-2010 the amount of funding of the state cultural policy decreased by $19.3 \%$ (from 83.8 billion to 67.6 billion of Russian roubles). The predicted amount of federal budget expenditure on cultural industry according to the data will be decreased in 2020 compared to actual data in 2015 by $17.8 \%$. The share of expenses on funding culture in the total amount of budget expenditure is decreasing as well during the whole period under study.

\subsection{Main results of realising the programme of the development of cultural sphere in Russia}

Basing on the preliminary data on executing the federal budget in 2017 we shall provide a more detailed characteristic of the indicators of budget funding of the state programme "The Development of Culture and Tourism in 2013-2020". In 2017 for implementing activities of the state programme 98.9 billion of Russian roubles were allocated from the federal budget; 90.2 billion of Russian roubles were disbursed which made $91.3 \%$ according to specified data [8]. The structure of expenses is presented in table 2. 
Table 2. Share of expenses on implementing subprogrammes of the state programme "The Development of Culture and Tourism in 2013-2020" in 2017

Per cents

\begin{tabular}{|l|c|}
\hline $\begin{array}{l}\text { Name of a subprogramme of the state programme "The Development of Culture } \\
\text { and Tourism in 2013-2020" }\end{array}$ & 2017 \\
\hline Subprogramme "Heritage" & 33.6 \\
\hline Subprogramme "Art" & 39.6 \\
\hline Subprogramme "Tourism" & 0.9 \\
\hline $\begin{array}{l}\text { Subprogramme "Providing conditions for implementing the state programme } \\
\text { "The Development of Culture and Tourism in 2013-2020" }\end{array}$ & 7.9 \\
\hline FTP "Russian Culture (2012-2018)" & 14.1 \\
\hline $\begin{array}{l}\text { FTP "The development of domestic and outbound tourism in the Russian } \\
\text { Federation (2011-2018)" }\end{array}$ & 3.9 \\
\hline Total & 100.0 \\
\hline
\end{tabular}

The ministry of Culture of the Russian Federation is the federal body of the executive authority that carries out functions to develop the state policy in the sphere of culture. In 2008 the Government of the Russian Federation once again approved the Regulation on the Ministry of Culture of the Russian Federation according to which it carries out "coordination and control over the activity of the subordinate Federal Service for Supervision over the Observance of the Law in the Sphere of Protecting Cultural Heritage and the Federal Archive Agency" [14].

State programmes during recent years are an important instrument of developing federal budget. It structure is formed in such a way that its each budget item corresponds to a main activity of a certain state programme. Budget planning and executing in subjects of the Russian Federation since 2014 has been carried out on a programme basis. The project management mode has a number of advantages that contribute to increasing the quality of budget management. The main advantages can include the following:

- $\quad$ Specific requirements for the quality of state management;

- Mobilising financial and human resources;

- $\quad$ Strict coordination of all involved structures and high personal responsibility;

- Increasing the openness for wide public information about the structure, directions and results of budgetary expenses carried out according to responsibilities of state authorities.

It is possible to claim with full justification that the state programmes in the sphere of culture, despite the limited resources in the federal budget expenditure part, make a universal financial instrument that can be implemented for all kinds of services in cultural and leisure sphere. The given approach maximises the 
provision of the focus orientation of funds, facilitates the monitoring of legitimacy and effectiveness of their use. Spending units can acquire financial resources envisaged by the programmes of financing their functions and activities on the condition that the expenses of a respective budget are approved. At the same time it is necessary to specify the limits of budgetary funding from the standpoint of dividing the services of the cultural sphere into classic and leisure ones. In the conditions of limited budget funding resources it is natural to manifest the tendency of developing the services of leisure character at a higher rate since it contributes to obtaining supplementary profits by the subjects of culture and culture institutions. In this case budget funds are not provided.

The budget funds can be allocated for financing cultural heritage objects of high value, leading federal establishments of cultural sphere and objects of all-Russian and regional importance that play an important role in the cultural life of the country and its regions. The above-mentioned types of institutions of culture are guided by the market principles, instruments and methods of economic management, although they are not aimed at commercial forms of activity. The combination of budgetary financing of culture with the elements of self-financing quite naturally fit into the structure of modern market mechanism.

\section{Discussion}

\subsection{Programme methods as an instrument of increasing the quality of budget funding}

The principles of classification of services in the sphere of culture depend on the industry specifics. At the same time the services of "culture" industry includes such kind of activities as commercial and noncommercial, local, national and international.

Being aware of the significance of culture and cultural environment in the development of modern society, we come to the conclusion that they should not and cannot function as a sphere of state interests exclusively. "Attracting extra-budgetary funds, mobilising cooperation with business and social movements and organisations become necessary conditions for preserving cultural-historical heritage and reproducing creative potential of the citizens" [7]. At the same time budget funding is necessary to provide government guarantees for preserving and developing culture in the Russian Federation. However, it is essential to create conditions to use the experience and practice of programme methods of planning and financing culture that have been obtained in Russia and abroad. "The transition from subsidising current expenses of organising culture to the investment of separate cultural projects has been a specific feature of the development of culture since the mid-1980s" [3]. The presented quote confirms the relevance and practical significance of the previous conclusions on the introduction of the elements of programme-target and effective approach to financial support of cultural and leisure industry. Specialists in the field of budget funding of socio-cultural sphere have repeatedly provided arguments for expedience of this financial tool. For instance, M.V. Koshkina notes that "the programme approach to financing non-commercial sector of the sphere of culture and art has been widely put in practice by the state". The author indicates that in modern economic conditions "the state cannot afford to finance culture and art by simple subsidy that does not involve, as a rule, strict target implementation" [11]. To solve the indicated issue and to increase the 
quality of budget planning and financing it is advisable to use the mechanisms of developing and applying target programmes.

The effectiveness of their use in the process of realising the state cultural policy is confirmed by the following aspects:

- Programmes like economic methods for regulating the cultural sector are not related to the financing the current activities of specific non-commercial organisations but are aimed at providing financial support of the priority type of cultural activity during the development and implementation of the programme;

- The programme approach as a characteristic feature of modern economic management creates the prerequisites and opportunities for the unification of various sources of financing the cultural programmes of the state;

- The development and implementation of cultural programmes by the state allows solving the issues of providing economic and legal guarantees for the protection of the professional interests of certain categories of subjects of cultural activities.

The cultural environment as a key notion of modern society cannot be an object of state regulation exclusively. To solve the current issues it is necessary to create and develop a multilevel system of regulating the process of cultural good that would take into account a great number of related factors and consolidate actions of various government bodies, public institutions and businesses. Federal and state target programmes are such financial instruments. Once more we shall agree with a number of authors and indicate that presently "budget funding carried out in accordance with the legislation of the Russian Federation remains the main form of financing the institutions of culture" $[9,26]$. At the same time it should be acknowledged that the conditions which would help to attract extra-budgetary funds for cultural sphere must be created in order to solve key problems of financing cultural institutions.

\subsection{Foreign experience of financial support of the cultural sphere}

"At the present stage the enlightened cultural policy will probably seek to establish such a coalition to achieve cultural goals of society and such a partnership that would enable government and nongovernment organisations as well as the corporate sector to obtain an incentive for mutual but not separate actions" [19].

As it was already noted, the researches of Russian and foreign scientists demonstrated that culture with full justification can be considered as a rather fast developing economic sector that makes a valid argument for the elaboration of strategies for socio-economic development of regions. There is a conviction that without support and without the revival of the social sector including such components as science, education and culture it is hard to count on economic progress. This conviction becomes more and more justified.

In order to use the positive elements in Russia the authors assessed the foreign practice of using the potential of culture in the development of economy and the possibilities of financing the cultural and leisure sector $[4,6]$. 
In the USA there is a practice of state budget allocations on culture and art for a specific project on the basis of justified application made by an organisation - recipient of funds; this application must be preliminary considered and approved by the expert council. At the same time the amount state financing cannot exceed $25 \%$ from the total value of the project [27]. To attract extra-budgetary funds a complex of tax reliefs is used. E.L. Shekova notes that among other developed countries of the world the United States is distinguished by a significant diversification of sources of funding in the sphere of culture. Non-commercial goals of economic activity dictate to the institutions of culture not only the development of their own preferential activities but also the attraction of external sources of financing from the state, the population and the private sector of the economy. In the USA cultural organisations have long been regarded from the standpoint of business aspect as partners for achieving common business goals. The term "corporate social investments" has come into use; it denotes allocations of resources made by commercial organisations for socially useful purposes. Every item of social expenditures of a corporation must be planned in advance and must have certain outcome. From the standpoint of institutions of culture corporate social investments take the form of charitable donations. Within the funds raised to finance culture in the USA and in European countries the following allocations should be singled out: charitable funds, insurance contributions, membership fees, various types of state subsidies, income from proper activities of cultural institutions, etc.

Summarising the analytical and practical issues on financing and state regulating of culture in the developed countries on the basis of previous publications we can draw the following conclusions:

- State financing of the sphere of culture prevails over the private one;

- The role of the local self-governing and non-government, non-commercial organisations increases;

- The activity of intermediary firms in the sphere of financing culture instead of direct donations from public funds acquires great importance;

- The state uses the mechanisms stimulating the participation of private capital in financing culture;

- The search of new sources of financing is carried out;

- The state supports not only institutions implementing projects and organising events in the sphere of culture but also individual creative activity;

- Cultural policy involves commercially oriented branches alongside traditional cultural institutions.

Many elements of positive foreign experience in financial support of culture can enter and must be used in Russian practice after the detailed study and testing. The authors of the given article plan to include the following issues into the sphere of their own scientific interests and goals of further research on the investigated problem: studying the tendency of the development of culture in Russia as a developing sector of economy; the analysis of the problems of developing and financing "culture" industry at a sub-federal level; participation in the development of measured indicators characterising qualitative and quantitative parameters of the sphere for the future, etc. Investigating the experience and problems of developing such 
an important budget instrument of state regulation of financial support of culture as regional target programmes is also included in the list of our plans.

\section{Conclusion}

"Culture" industry in the Russian Federation functions in the conditions of decreasing in the share of budget financing, thus, to make a conclusion on the directions and priorities of its development is rather difficult. Within the framework of state cultural policy and in the sphere of culture attempts to intensify instruments and methods of budget policy by means of developing and realising state and federal target programmes are made. However, the amount of financing envisaged it them can be called "symbolic". For instance, the share of financing the state target programme "The Development of Culture and Tourism in 2013-2020" constitutes $0.5-0.6 \%$ from the total amount of expenditures of the federal budget.

Basing on "studying the functions of governing bodies and economic entities in the sphere of culture in the Russian Federation the following conclusion should be drawn: the principle of determining priorities in the process of undertaking cultural activities is a state and public one". Following this principle it is necessary "to connect the interests of the state and professional groups and to share responsibility for decisionmaking between the bodies of state management, social organisations and experts in the field of culture and art" [7]. Unfortunately, according to the data on realising framework the Federal Target Programme (FTP) "Culture of Russia (2012-2018)" the state did not manage to create necessary conditions for attracting extra-budgetary funds to finance the cultural sphere. During the period of its implementation the annual financing from the federal budget resources that would total 20.5 billion of Russian roubles is envisaged, whereas the amounts of attracted finances from other sources would make only 486 million of Russian roubles.

"The state policy in the sphere of culture must enable to create conditions for proving the citizens with the guaranteed number of services as well as to ensure guarantees of any organisational-legal forms to the service providers for carrying out activities". As can be deduced from the practice of financing the branches of cultural and leisure activities budgetary allocations from the federal budget alone are not clearly enough for this purpose. The realisation of the programme activities in the sphere of culture and the volumes of its financing, in our opinion, can contribute to solving the state policy tasks connected with preserving cultural and historical heritage only on a minimum scale.

The financial policy in the sphere of culture based on performing its functions as in any other branches of economy must be founded on the system of measured indicators in order to assess the results and perspectives of the development of a particular sector. The great diversity in the types of cultural institutions, the variety of their activities and the economic and social effects that they produce create certain difficulties in the development of such a system of criteria for assessment of the effectiveness of functioning of both the "culture" industry in general and its individual organisations and activities. To resolve this issue further research is needed both within the framework of the formation of new approaches to financing expenditures on the cultural sphere of the country and for the development of a system of 
indicators reflecting the results of work of cultural institutions. The proposed criteria can be used afterwards as a basis for the process of forming, distributing and using budgetary funds for the programme activities of this branch of economy.

"In these conditions the model of budgeting aimed at the final result can and must be modified into the model of functionally oriented financing" $[7,12]$.

The algorithm of actions in the given situation, according to the authors' opinion, must be structured in the following way:

- Setting goals with singling out priorities and allocating necessary amounts of financial resources on the basis of the complex analysis of the situation in the sphere in general and in a particular establishment of culture;

- Substantiating the opportunity to use financial instruments and methods the application of which will enable to effectively solve the set goals and objectives;

- Competent management from the standpoint of personnel factor, distributing duties and responsibilities; - Asessing the planned and actual results of programme activities and comparing them with the expenses;

- Forecasting goals, indicators of assessing the results, reconciliation of indicators of the sphere development with the opportunity of their financial support and substantiating the development perspectives.

\section{Conflict of interest}

The authors confirm that the data do not contain any conflict of interest.

\section{References}

Budget for Citizens (2017). To the federal law on federal budget for 2017 and for the planned period 20182019. Available at: https://www.minfin.ru/ru/document/?id_4=116961 (Accessed 3.04.2018).

Budget for Citizens (2017). To the project of the federal law on federal budget for 2018 and for the planned period 2019-2020. Available at: https://www.minfin.ru/ru/document/?id_4=119762 (Accessed 3.04.2018). 
Chistova, M. V. \& Demina, N. V. (2016). The system of financing activities of institutions of culture in the Russian Federation. Scientific and methodological electronic journal "Koncept", vol.2, pp. 121-125. Available at: http://e-koncept.ru/2016/46025.htm (Accessed 25.02.2018).

Cultural policy and cultural management (2003). Collective monograph. Saint Petersburg State Academy of Theatrical Art, the Department of Management of Performing Arts.

Federal Law No.198-FL of 24 June 2007 "On federal budget for 2008 and for the planned period 2009-2010". (Edition of 08.11.2008). Available at: https://www.minfin.ru/ru/document/?id_4=5521 (Accessed 17.01.2018).

Federal target programme "Russian Culture (2006-2010)". Approved by the decree of the government of the Russian Federation No.740 on 08.12.2005. Available at: https://www.lawmix.ru/zkrf/3209 (Accessed 17.01.2018).

Federal target programme "Russian Culture (2012-2018)". Approved by the decree of the government of the Russian Federation No.186 on 3.03.2012. Available at: http://docs.cntd.ru/document/902335243 (Accessed 20.02.2018).

Flier, A. Ya. (2000). Cultural studies for culture experts. Training manual for master's degree students, postgraduates and doctor's degree students. Moscow: Academic Project.

Kargapolov, V. E. (2006). Economic culture of a person, society and state. The modern issues of science and education. No.3. Available at: http://science-education.ru/ru/article/view?id=364 (Accessed 13.04.2018).

Koshkina, M. V. (2004). State financing of culture and art. Finances. No.3, pp. 70-72.

Landry, C.; Green, L.; Matarasso, F. \& Bianchini, F. (1999). The art of regeneration. Urban renewal through cultural activity. (Translation). Saint Petersburg: Notabene.

Lazareva, G. I. (2012). The priorities of social policy of the Russian Federation and its specific features at a regional level. International scientific-theoretical journal. The bulletin of Belgorod University of Cooperation, Economics and Law. No.1 (41), pp. 153-162.

On the Ministry of Culture of the Russian Federation. The decree of the government of the Russian Federation of 29.05.2008 No.406 (Edition of 20.07.2011). Available at: https://www.lawmix.ru/prof/2731 (Accessed 5.03.2018).

Repina, L. P. (2001). Cultural shift in intellectual history. The choice of methods: studying culture in Russia in 1990s. Moscow: Russian State University for the Humanities, pp. 28-36.

Report on the culture of the world cities (2015). Moscow: Publishing House of Moscow Institute of Sociocultural Programmes. Available at: http://docplayer.ru/25817578-Doklad-gorodov-mirovyh-o-kulture.html (Accessed 3.04.2018).

Romanovsky, M. V.; Vrublevskaya, O. V. \& Sabatni, B. M. (eds.) (2006). Finances: Manual (2 ${ }^{\text {nd }}$ ed.). Moscow: Urait Publishing House. 
Sayapina, E. I. \& Strizhova, N. A. (2015). Culture in the life of modern Russian society. Modern scientific researches and innovations. No.9. Part 2. Available at: http://web.snauka.ru/issues/2015/09/57264 (Accessed 29.01.2018).

Shekova, E. L. (2003). The sources of financing culture in the USA. The world economy and international relations, No.2, pp. 52-56.

The conception of long-term socio-economic development of the Russian Federation up to 2020. Available at: http://74330s020.edusite.ru/DswMedia/koncepciyadolgosrochnogosocial-noyekonomicheskogorazvitiyarossiyskoyfederaciinaperioddo2020goda.pdf (Accessed 9.04.2018).

The Fundamentals of the Legislation of the Russian Federation on Culture (approved by the Supreme Court of the Russian Federation 09.10.1992 No.3612-1). (Edition of 05.12.2017). Available at: http://legalacts.ru/doc/osnovy-zakonodatelstva-rossiiskoi-federatsii-o-kulture-utv/ (Accessed 15.03.2018).

The implementation of the federal budget and of budgets of the budgetary systems of the Russian Federation in 2017 (preliminary results). Available at: https://www.minfin.ru/common/upload/library/2018/03/ main/Ipolnenie_federalnogo_budzheta.pd (Accessed 9.04.2018).

The specific features of forming the expenses of federal budget in the social sphere in 2018-2020. Available at: http://docplayer.ru/66953072-Osobennosti-formirovaniya-rashodov-federalnogo-byudzheta-votraslyah-socialnoy-sfery-v-g.htmlhttp://docplayer.ru/66953072-Osobennosti formirovaniya-rashodovfederalnogo-byudzheta-v-otraslyah-socialnoy-sfery-v-g (Accessed 12.04.2018).

Throsby, D. (2013). Economics and culture. (Translation). Moscow: Publishing House of National Research University Higher School of Economics.

Tulchinsky, G. L. \& Shekova, E. L. (2009). Management in the sphere of culture. Training manual. Saint Petersburg: Publishing House "Lan".

Yefimova, S. B. \& Remizov, E. A. (2005). State expenditure policy and financial control in social sphere. Saratov: SSSEU.

Yefremova, L. A. (2009). Functionally oriented financing of culture. Cand. Diss. SEI HPE "Saint Petersburg State University of Economics and Finance".

Yefremova, L. A. (2015). Foreign experience of financing culture and leisure services. Proceedings from the first annual international scientific-practical readings of Stavropol Institute of Cooperation (Branch of BUCEL). Stavropol: LLC "Fabula", pp. 53-56. 